\title{
Effect of Nitrogen Rate and Application Ratio on Late Sown Sunflower in Wet Soil under Zero Tillage in the Coastal Zone of Southwestern Bangladesh
}

\author{
Bidhan Chandro Sarker, Md. Yasin Ali, Richard W. Bell, Md. Enamul Kabir
}

10.18805/IJARe.A-671

\begin{abstract}
Background: The cropping pattern of southwestern (SW) coastal Bangladesh has been improving from Fallow-Fallow-Transplanted aman paddy to Sunflower-Fallow-Transplanted aman paddy. The emerging cropping pattern of SW Bangladesh from single transplanted aman paddy to double cropping, sunflower in winter after transplanted aman paddy needs new crop husbandry including nutrient management particularly nitrogen $(\mathrm{N})$. Hence, the present study aimed to evaluate the yield response of late sown sunflower to rates and application ratio (basal:top dressed) of $\mathrm{N}$ in the coastal soil of SW Bangladesh.

Methods: The field experiment was conducted during winter season (2018-19) in a randomized complete block design and replicated thrice. The experimental treatments consisted of seven $\mathrm{N}$ rates $\left(0,60,90,120,150,180\right.$ and $\left.210 \mathrm{~kg} \mathrm{ha}^{-1}\right)$ and three application ratio (50\%:50\%, 25\%:75\% and $0 \%: 100 \%$ ).

Result: Results revealed that with the increased of $\mathrm{N}$ rates, dry matter, seed yield, yield attributes and net income were substantially increased: the highest values of these parameters were found at 150 and $180 \mathrm{~kg} \mathrm{~N} \mathrm{ha}^{-1}$ when applied @ ratio of 25\%:75\% (basal: top dressed) despite non-significant interaction while the agronomic efficiency was higher at $60 \mathrm{~kg} \mathrm{ha}^{-1}$ next decreased. The findings of the study suggested that $\mathrm{N} @ 150 \mathrm{~kg} \mathrm{ha}^{-1}$ with $25 \%: 75 \%$ application ratio is suitable for late sown sunflower in the coastal soil of SW Bangladesh.
\end{abstract}

Key words: Agronomic efficiency, Net income, Nitrogen, Seed yield, Sunflower.

\section{INTRODUCTION}

Transplanted aman paddy is the single crop in the coastal soil of southwestern Bangladesh and in the dry season most of the land remains fallow due to excess soil wetness during sowing, lack of fresh irrigation water, soil and water salinity. Recently copping intensity in this region has been improving from single to double crop (Paul et al., 2020). Among the crop tested to fit in dry (winter) season (December-May) sunflower has proved a suitable and promising crop in this region because of its moderate salt and drought tolerance and low irrigation requirement (Paul et al., 2020). For the emerging cropping pattern, the agronomic practices including fertilizer management needs to be developed because the recommendation of fertilizer is available only for Transplanted aman paddy, no nutrient recommendation including $\mathrm{N}$ remains available for sunflower.

Sunflower (Helianthus annuus L.) is the world's fourth largest and important oil seed crop next to soybean that contains $40-52 \%$ oil and $13-20 \%$ protein (Brar et al., 2016). County's current domestic edible oilseed production is 373 thousand tons, which meets only one third of national demand (BBS, 2011). Sunflower was determined as a moderately sensitive crop to salinity (Katerji et al., 2003). Sunflower can be cultivated at diverse sowing dates and it is very efficient user of soil moisture as a result of its deep and branched tap root system penetrating to deeper zone, aids the plant during water stress (Paul et al., 2020). In the coastal soil of SW Bangladesh early sowing of sunflower is
Agrotechnology Discipline, Life Science School, Khulna University, Khulna-9208, Bangladesh.

Corresponding Author: Bidhan Chandro Sarker, Agrotechnology Discipline, Life Science School, Khulna University, Khulna-9208, Bangladesh. Email: bsarker2000@gmail.com

How to cite this article: Sarker, B.C., Ali, M.Y., Bell, R.W. and Kabir, M.E. (2022). Effect of Nitrogen Rate and Application Ratio on Late Sown Sunflower in Wet Soil under Zero Tillage in the Coastal Zone of Southwestern Bangladesh. Indian Journal of Agricultural Research. DOI: 10.18805/IJARe.A-671.

Submitted: 22-06-2021 Accepted: 02-12-2021 Online: 15-01-2022

difficult due to late harvest of transplanted aman paddy. On the other hand, sowing in later crops suffer from soil moisture deficit, soil salinity and irrigation water salinity.

The fertility status of coastal soils of SW Bangladesh ranges from low to very low in respect of nitrogen and organic carbon (Paul et al., 2020). Among the essential nutrient elements, $\mathrm{N}$ is the most yield limiting element and its deficiency is the most prominent nutritional disorder greatly affecting the sunflower yield (Oyinlola et al., 2010). N substantially affects the vegetative, reproductive, physiological and metabolic process of crop plants (Massignam et al., 2009). Appropriate scheduling of $\mathrm{N}$ had marked influence on growth and yield of crops (Khatik et al., 2020). In the SW coastal region zero tillage is the only option to cultivate crops timely after transplanted aman 
paddy. It is important to investigate how sunflower responds to $\mathrm{N}$ management in the initial wet and later dry soil. Amount and time of $\mathrm{N}$ application are vital for efficient $\mathrm{N}$ management. For the maximization of effective $\mathrm{N}$ fertilizer use, it is essential to determine proper time and accurate ratio of $\mathrm{N}$ application. $\mathrm{N}$ fertilization is more effective when schedule between floret initiation and anthesis other than application at various stages (Steer et al., 1984) under nonsaline and full tillage condition.

A good opportunity exists to create an impact on crop performance by implementing sustainable and profit-making $\mathrm{N}$ management practices for the emerging cropping systems in the SW coastal region of Bangladesh. Therefore, the field study was carried out to find out the suitable rates and proper application ratio (basal: top dressed) of $\mathrm{N}$ for late sown sunflower under zero tillage in the coastal soils of SW Bangladesh.

\section{MATERIALS AND METHODS}

The experiment was conducted in the farmer's field of Pankhali (Latitude-22 $38^{\prime} \mathrm{N}$, Longitude-89 $30^{\prime} \mathrm{E}$ and elevation $\sim 2-3 \mathrm{~m}$ above the sea level), Dacope, Khulna in the southwestern coastal region of Bangladesh during December, 2018 to April, 2019. During the growing season total amount of rainfall was $\sim 350 \mathrm{~mm}$, the lowest and highest temperature ranged between $12-27^{\circ} \mathrm{C}$ and $24-35^{\circ} \mathrm{C}$, respectively (Fig $1 \mathrm{~A}-\mathrm{B}$ ). The soil of the experimental field was silty clay having total nitrogen and organic matter content 0.09 and $1.83 \%$, respectively.

The experiment was laid out in a factorial randomized complete block design with three replications. The experimental treatments were seven $\mathrm{N}$ levels (viz. 0, 60, $90,120,150,180$ and $210 \mathrm{~kg} \mathrm{ha}^{-1}$ ) and three $\mathrm{N}$ application ratio as basal:top dressed (50\%:50\%, 25\%:75\% and 0\%:100\%). All the experimental plot received P, K and S @ 50,90 and $30 \mathrm{~kg} \mathrm{ha}^{-1}$, respectively. Treated (Provax-200) seed (Hysun-33) were dibbled on $25^{\text {th }}$ December in wet soil (Gravimetric soil moisture content $\sim 42 \%$ ) at a spacing of 70 $\mathrm{cm} \times 40 \mathrm{~cm}$. All the fertilizers and the selected rate and ratio of $\mathrm{N}$ (source: urea) were applied in both sides of the seed along the row in the hole ( $6-7 \mathrm{~cm}$ depth) making by bamboo peg and then covered the hole. The rest amount of urea was applied on the soil surface in equal splits at 20 and 40 days after emergence (DAE) followed by irrigation, thus the amount of $\mathrm{N}$ in different splits were also varied. One weeding and four irrigations were given during the cultivation period. The crop was harvested on $20^{\text {th }}$ April, 2019. Data on growth, yield attributes, seed yield were recorded and subsequently agronomic efficiency (AE) of N, net income and benefit-cost ratio were calculated. Leaf greenness was measured at different growth stages using leaf chlorophyll content meter (CCM-200; Opti-Sciences, USA). All the data were compiled and statistically analysed following the analysis of variance (2-way ANOVA) using 'Statistix-10'. The treatment means were separated by Duncans' multiple range test (DMRT) at $5 \%$ level of probability (Gomez and Gomez, 1984).

$$
\mathrm{AE}=\frac{\begin{array}{c}
\text { Seed yield with } \mathrm{N} \\
\text { addition plot }(\mathrm{kg} / \mathrm{ha})
\end{array}-\begin{array}{c}
\text { Seed yield without } \\
\mathrm{N} \text { addition }(\mathrm{kg} / \mathrm{ha})
\end{array}}{\text { Rate of } \mathrm{N} \text { addition }(\mathrm{kg} / \mathrm{ha})}
$$

\section{RESULTS AND DISCUSSION}

\section{Growth parameters}

Plant growth was significantly enhanced with the increased rate of $\mathrm{N}$ (Table 1). Application of $\mathrm{N} @ 180 \mathrm{~kg} \mathrm{ha}^{-1}$ resulted the higher plant height and stem diameter at $75 \mathrm{DAE}$ which was statistically at par with 150 and $210 \mathrm{~kg} \mathrm{ha}^{-1}$ while the higher stem diameter was resulted in $210 \mathrm{~kg} \mathrm{ha}^{-1}$ which was on parity with 150 and $180 \mathrm{~kg} \mathrm{ha}^{-1}$. The response of sunflower growth was due to an increase levels of $\mathrm{N}$ from the initial negligible or low soil $\mathrm{N}$ (Table 1 ) and rectify the $\mathrm{N}$ deficiency and leads to vigorous growth. Increased levels of $\mathrm{N}$ enhanced leaf chlorophyll content, produced more carbohydrate and promote the vegetative growth of the plant (Chantal et al., 2018 and in the current study). Application of $\mathrm{N} @ 25 \%$ basal:75\% top dressed significantly produced the tallest plant with highest stem girth (Table 1). This was due to the better timing and distributing $N$ as per the requirement of plant at different growth stages whereas in $0 \%$ basal: $100 \%$ top dressed treatment, plant growth was comparatively poor possibly due to the deficiency of initial $\mathrm{N}$ requirement. Timely scheduling and splitting of $\mathrm{N}$ affected the growth and yield attributes of sunflower (Khanzada et al.,

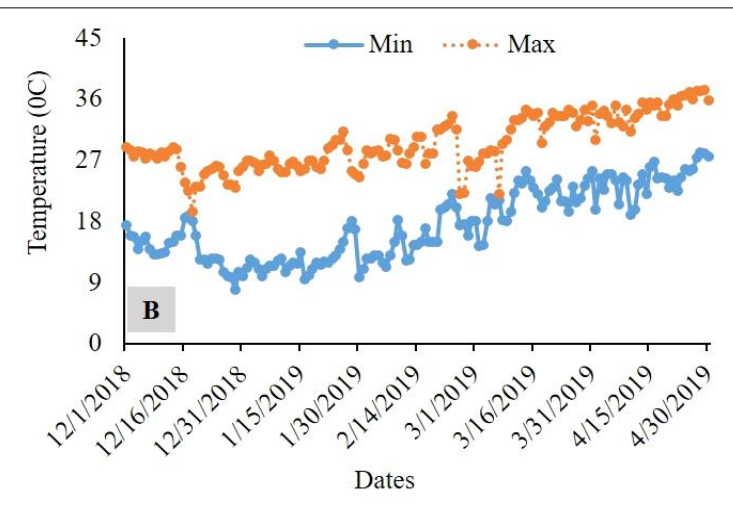

Dates

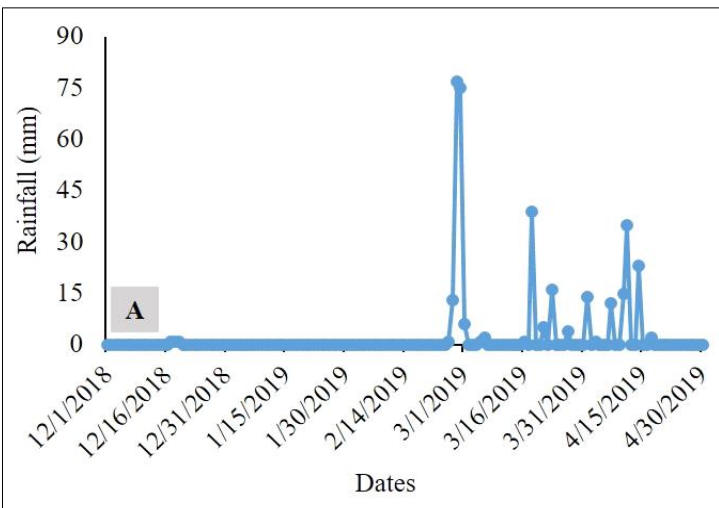

Fig 1: Rainfall (A) and temperature (B) pattern in the study area during the cultivation period in the southwestern coastal region of Bangladesh. 
Effect of Nitrogen Rate and Application Ratio on Late Sown Sunflower in Wet Soil under Zero Tillage in the Coastal Zone...

2016). The interaction of $\mathrm{N}$ rate and application ratio had no significant effect on plant growth.

\section{Dry matter (DM) and yield attributes}

Dry matter (DM) and yield attributes were substantially influenced with the $\mathrm{N}$ rate and application ratio, but their interaction effect was insignificant (Fig 2A-B and Table 1). Among the rates of $\mathrm{N}$, the highest DM accumulation, head diameter, number of seed head ${ }^{-1}$, harvest index were obtained in $180 \mathrm{~kg} \mathrm{~N} \mathrm{ha}^{-1}$ but 1000 seed weight was higher in $210 \mathrm{~kg} \mathrm{ha}^{-1}$. On the other hand application of $\mathrm{N} @ 25 \%$ as basal:75\% as top dressing resulted in higher DM accumulation, head diameter, number of seed head ${ }^{-1}, 1000$ seed weight and harvest index compared to other application ratio. Growth and yield of sunflower largely associated with the availability of nutrients of which $\mathrm{N}$ plays a vital role having a positive influence on the yield attributes and seed yield due to the higher rate of photosynthesis (Awais et al., 2017).
Leaf chlorophyll content increased with the increased rate of $N$ (Fig 3A), which lead to accumulated more photosynthates and finally enhanced the DM accumulation (Qahar et al., 2010). Ravishankar and Malligawad (2017) showed that DM accumulation enhanced with the increased levels of $\mathrm{N}$ application irrespective of other nutrients. Head diameter increased with the increased rate of $\mathrm{N}$ due to adequate supply of $\mathrm{N}$ which stimulated higher head diameter (Ullah and Akmal, 2018) that accommodated more number of seeds head ${ }^{-1}$. Nasim et al. (2012) testified that 1000 seed weight increased with the increment of $\mathrm{N}$ rates. Yield attributes were higher in $25 \%$ basal: $75 \%$ top dressed application of $\mathrm{N}$ might be due to timely splitting and utilization of N. Khanzada et al. (2016) reported that yield attributes positively influenced by the three-equal splitting of $\mathrm{N}$. Other than rate, timing of $\mathrm{N}$ application was another crucial aspect that greatly influenced the yield traits and yield. Basal

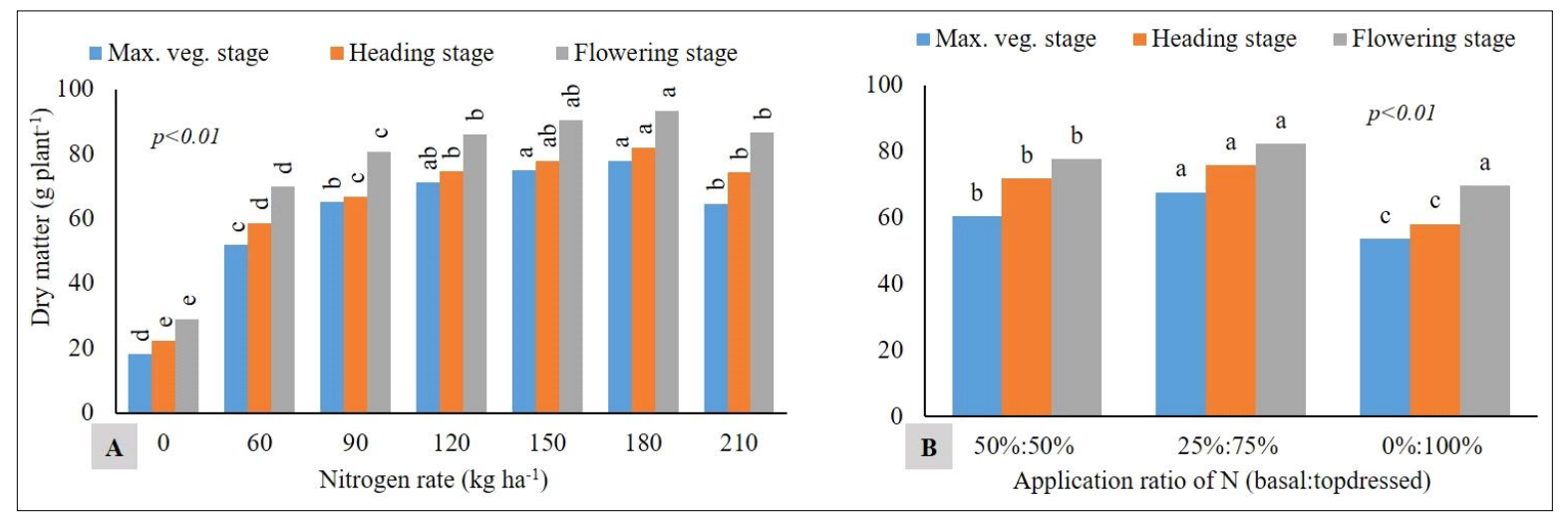

Fig 2: Effect of rates $(A)$ and application ratio $(B)$ of $N$ on dry matter accumulation of sunflower grown in the coastal soil of southwestern Bangladesh.

Table 1: Effect of rate and application ratio of $\mathrm{N}$ on growth and yield attributes of sunflower grown under zero tillage in the southwestern coastal soil of Bangladesh.

\begin{tabular}{|c|c|c|c|c|c|c|}
\hline Treatments & $\begin{array}{l}\text { Plant height } \\
(\mathrm{cm})\end{array}$ & $\begin{array}{l}\text { Stem dia. } \\
(\mathrm{cm})\end{array}$ & $\begin{array}{l}\text { Head dia. } \\
\quad(\mathrm{cm})\end{array}$ & $\begin{array}{l}\text { Seed } \\
\text { head }^{-1}\end{array}$ & $\begin{array}{l}1000 \text { seed } \\
\text { weight }(\mathrm{g})\end{array}$ & $\begin{array}{r}\text { Harvest } \\
\text { index }(\%)\end{array}$ \\
\hline \multicolumn{7}{|c|}{ Nitrogen rates $\left(\mathrm{kg} \mathrm{ha}^{-1}\right)$} \\
\hline 0 & $69.22 d$ & $4.21 \mathrm{e}$ & $10.32 e$ & $626 e$ & $38.56 \mathrm{e}$ & $35.81 \mathrm{e}$ \\
\hline 60 & $122.54 \mathrm{c}$ & $7.48 d$ & $16.34 d$ & $1026 d$ & $54.21 \mathrm{~d}$ & $37.25 d$ \\
\hline 90 & $129.70 b$ & $7.98 \mathrm{c}$ & $17.84 \mathrm{c}$ & $1124 c$ & $63.30 \mathrm{c}$ & $38.32 \mathrm{c}$ \\
\hline 120 & 131.97ab & $8.02 b c$ & $18.54 a b c$ & $1202 b$ & $66.74 \mathrm{bc}$ & $39.19 b$ \\
\hline 150 & 133.63ab & $8.43 a b$ & 18.88ab & $1274 b$ & $70.12 \mathrm{ab}$ & $39.87 a b$ \\
\hline 180 & $136.39 a$ & $8.63 a$ & $19.26 a$ & $1349 a$ & $71.79 a$ & $40.33 a$ \\
\hline 210 & 131.72ab & $8.76 a$ & $18.24 \mathrm{bc}$ & $1221 b$ & $73.40 a$ & $39.22 b$ \\
\hline SE $( \pm)$ & 2.72 & 0.22 & 0.44 & 36.1 & 1.77 & 0.40 \\
\hline $\mathrm{p}$ level & $<0.01$ & $<0.01$ & $<0.01$ & $<0.01$ & $<0.01$ & $<0.01$ \\
\hline \multicolumn{7}{|c|}{ Application ratio of nitrogen (basal: top dressed) } \\
\hline $50 \%: 50 \%$ & $123.07 a$ & $7.85 a$ & $17.14 \mathrm{ab}$ & $1121.2 a$ & $63.05 b$ & $38.51 \mathrm{~b}$ \\
\hline $25 \%: 75 \%$ & $124.83 a$ & $7.73 a$ & $17.42 a$ & $1168.9 a$ & $65.14 a$ & $39.27 a$ \\
\hline $0 \%: 100 \%$ & $118.60 b$ & $7.35 b$ & $16.61 b$ & $1062.6 c$ & $59.58 \mathrm{c}$ & $37.93 c$ \\
\hline SE $( \pm)$ & 1.78 & 0.14 & 0.29 & 23.71 & 1.16 & 0.26 \\
\hline $\mathrm{p}$ level & $<0.01$ & $<0.01$ & $<0.05$ & $<0.05$ & $<0.01$ & $<0.01$ \\
\hline
\end{tabular}

SE-Standard error; Figure in a column having similar letter do not differ significantly. 
application of $\mathrm{N}$ is crucial for early vegetative growth but excess $(>25 \%)$ had no significant influence possibly due to low plant demand rather $\mathrm{N}$ application is more functional when scheduled between floret initiation to anthesis (Steer et al., 1984).

\section{Seed and stover yield}

Seed yield and stover yield varied significantly with the application of $\mathrm{N}$ rate or application ratio of $\mathrm{N}$ individually (Fig 4A-D) but their interaction was not significant. The higher seed yield (3.27 tha-1) and stover yield (4.84 tha-1) were attained with the application of $180 \mathrm{~kg} \mathrm{~N} \mathrm{ha}^{-1}$ while it was found on parity with $150 \mathrm{~kg} \mathrm{~N} \mathrm{ha}^{-1}$. Application of N @ 25\% basal:75\% top dressed resulted substantially higher seed yield $\left(2.62 \mathrm{t} \mathrm{ha}^{-1}\right)$ and stover yield $\left(3.97 \mathrm{t} \mathrm{ha}^{-1}\right)$. Seed yield was improved by $\sim 1.7$ times to $\sim 3.4$ times more from 60 to $180 \mathrm{~kg} \mathrm{~N} \mathrm{ha}^{-1}$ afterwards dropped by $\sim 13 \%$ in $210 \mathrm{~kg} \mathrm{~N} \mathrm{ha}^{-1}$.
The higher seed yield was ascribed due to the highest head diameter, seed head ${ }^{-1}$ and 1000 seed weight. There exists a positive relationship between yield and nitrogen rates due to higher dry matter accumulation and more biomass partitioning to seed yield (Ayadi et al., 2015). This improvement of yield was due to better allocating of photosynthates to the reproductive parts resulting in higher seed yield (Qahar et al., 2010). 25\% basal:75\% top dressed application of $\mathrm{N}$ raised the seed yield by $4 \%$ and $16 \%$ as compared to $50 \%$ basal: $50 \%$ top dressed and $0 \%$ basal: $100 \%$ top dressed, respectively due be the better splits and amount of $\mathrm{N}$ applied depending on growth stages and crop requirement. It is noted that $\mathrm{N}$ application between floret initiation and anthesis may increase the seed yield as the sunflower roots absorb $\mathrm{N}$ from soil up to seed filling stage (Goswami and Srivastava, 1988).

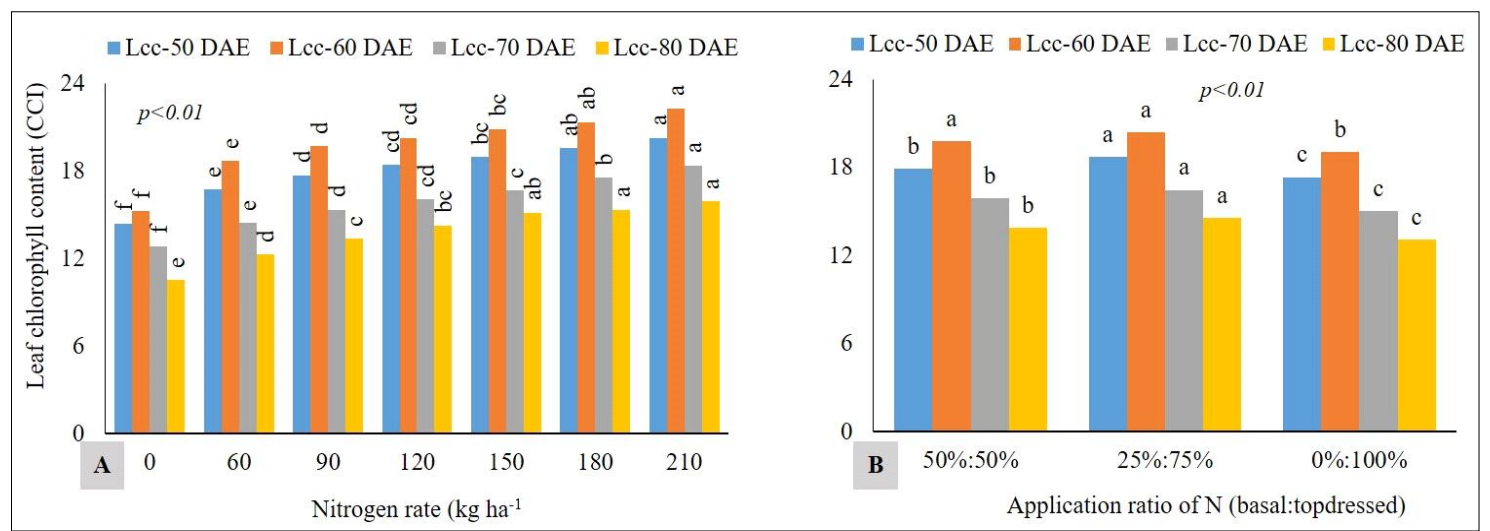

Fig 3: Effect of rates (A) and application ratio (B) of $\mathrm{N}$ on leaf chlorophyll content of sunflower grown in the coastal soil of southwestern Bangladesh

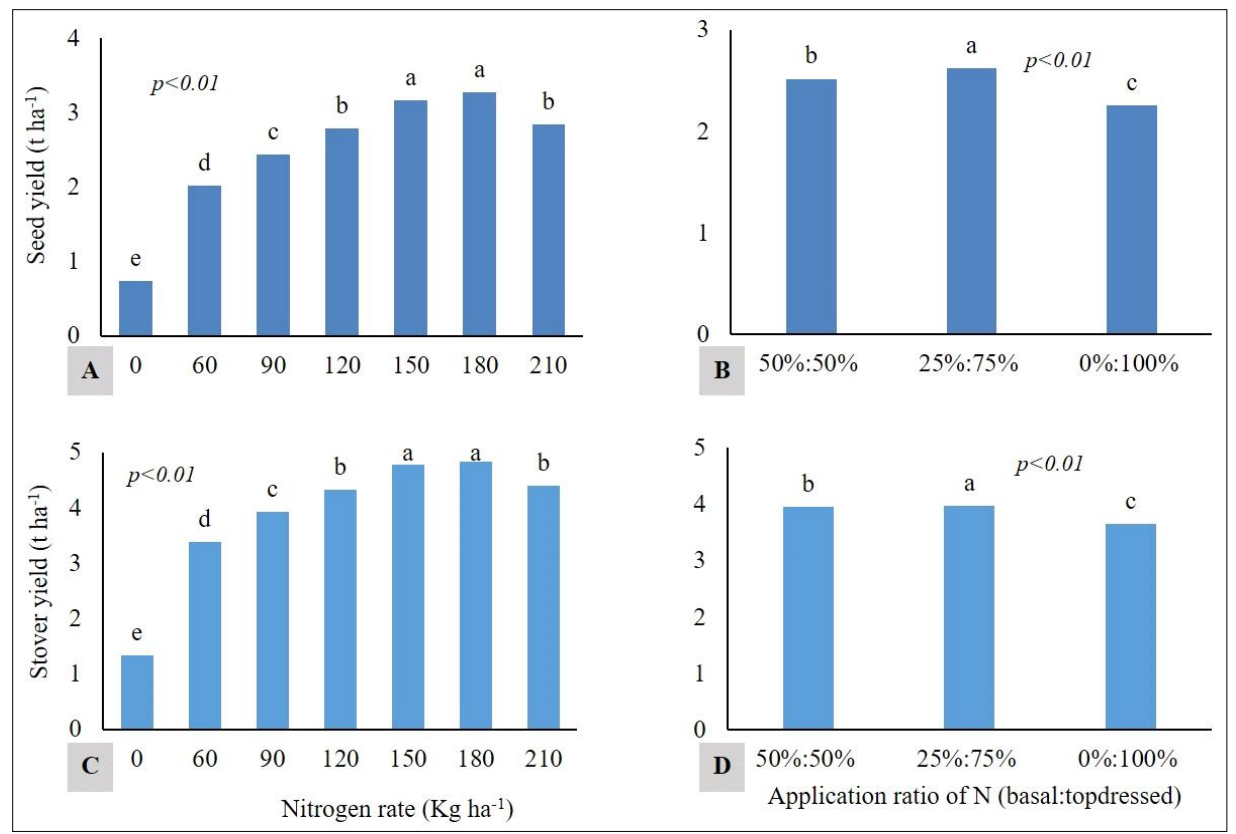

Fig 4: Effect of rates and application ratio of $N$ on seed yield $(A$ and $B)$ and stover yield $(B$ and $C)$ of sunflower grown in the coastal soil of southwestern Bangladesh. 


\section{Seed oil content and oil yield}

Seed oil content significantly decreased with the increased rate of $\mathrm{N}$ from 0 to $210 \mathrm{~kg} \mathrm{ha}^{-1}$ but $\mathrm{N}$ application ratio and their interaction was not significant (Fig $5 A-B)$. This was might be due to higher accumulation of proteins, decreasing the availability of carbohydrates for polymerization into fatty acid causing lower seed oil concentration (Ali and Ullah, 2012). Significantly the higher oil yield $\left(1249.6 \mathrm{~kg} \mathrm{ha}^{-1}\right)$ was resulted in $180 \mathrm{~kg} \mathrm{~N} \mathrm{ha}^{-1}$ which was statistically at par with $150 \mathrm{~kg} \mathrm{ha}^{-1}$. Oil yield was gradually raised up to $180 \mathrm{~kg} \mathrm{~N} \mathrm{ha}^{-1}$ due to the gradual increase in seed yield afterwards declined by $15 \%$ in 210 $\mathrm{kg} \mathrm{N} \mathrm{ha-1}$. Ali and Ullah (2012) observed the similar trend that oil yield increased due to increase in seed yield with the increased of $\mathrm{N}$ application. In the application ratio, significantly higher oil yield (1020.7 $\left.\mathrm{kg} \mathrm{ha}^{-1}\right)$ was obtained from $25 \%$ basal: $75 \%$ top dressed.

\section{Agronomic efficiency}

Among the $\mathrm{N}$ rates, $\mathrm{AE}$ was significantly higher in $60 \mathrm{~kg} \mathrm{ha}^{-1}$ then declined by 12 to $53 \%$ from 90 to $210 \mathrm{~kg} \mathrm{ha}^{-1}$ i.e., $\mathrm{AE}$ was inversely related to the nitrogen rates (Fig 6A-B). Qahar et al. (2010) noted that nitrogen use efficiency decreased with the increased of $\mathrm{N}$ levels. Among the application ratio, $25 \%$ basal: $75 \%$ topdressed resulted the higher $\mathrm{AE}$ which was $6-25 \%$ more than other application ratio.

\section{Economic analysis}

The cost of cultivation steadily increased from BDT 94749.0 to 102205.0 with the increased of $N$ rates from 60 to 210 $\mathrm{kg} \mathrm{ha}^{-1}$. Net income and benefit-cost ratio (BCR) were significantly varied with the variation of $\mathrm{N}$ rates and application ratio of $\mathrm{N}$, however, their interaction was not significant (Fig 7A-D). The highest net income (BDT $51258.0)$ and BCR (1.51) were calculated from $180 \mathrm{~kg} \mathrm{~N}$ ha-1 which was statistically at par to that of $150 \mathrm{~kg} \mathrm{~N} \mathrm{ha}^{-1}$ (BDT 48288.0 and 1.48, respectively). In the application ratio, the higher net return (BDT 29904.0) and BCR (1.28) were achieved from $25 \%$ basal: $75 \%$ top dressed application of $\mathrm{N}$. The higher net income and BCR in 150$180 \mathrm{~kg} \mathrm{~N} \mathrm{ha}^{-1}$ and $25 \%$ basal: $75 \%$ top dressed application of $\mathrm{N}$ resulted due to the higher seed yield as compared to other rates and application ratio of $\mathrm{N}$. As the land remain fallow in the dry winter in the SW coastal Bangladesh, farmers can get return of BDT $\sim 50,000.0$ from sunflower cultivation by applying $150 \mathrm{~kg} \mathrm{~N} \mathrm{ha-1.}$

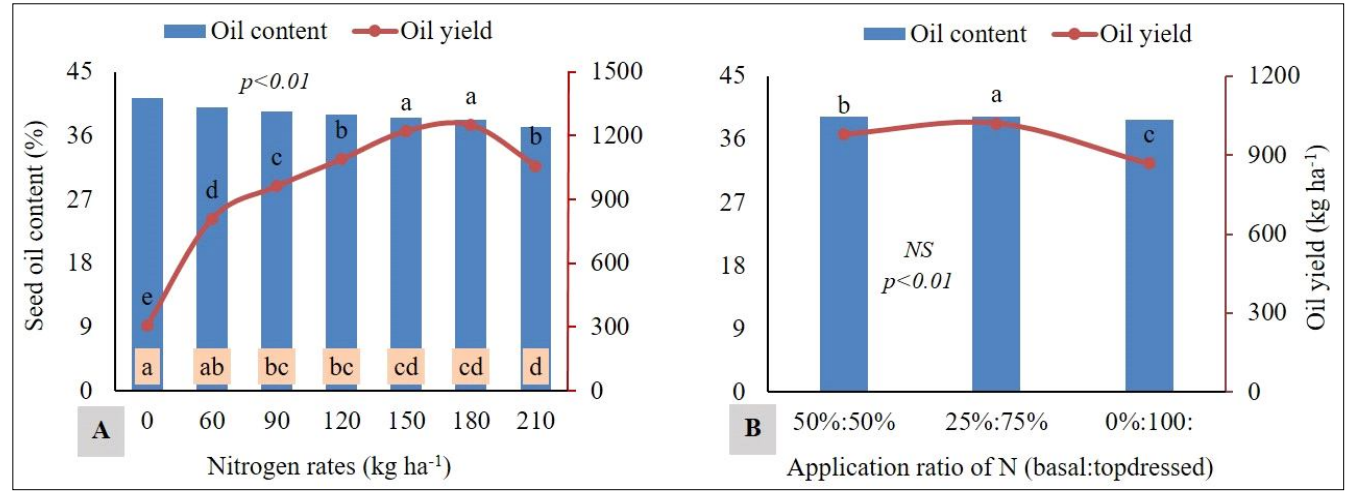

Fig 5: Effect of rates $(A)$ and application ratio $(B)$ of $N$ on seed oil content and oil yield (of sunflower grown in the coastal soil of southwestern Bangladesh.

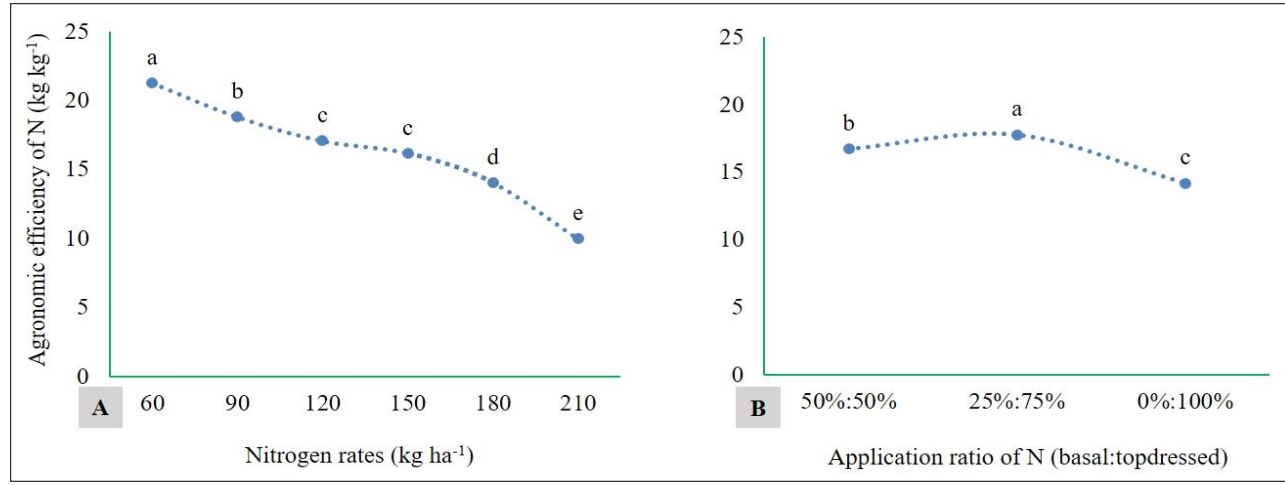

Fig 6: Effect of rates (A) and application ratio (B) of $\mathrm{N}$ on agronomic efficiency yield of sunflower grown in the coastal soil of southwestern Bangladesh. 


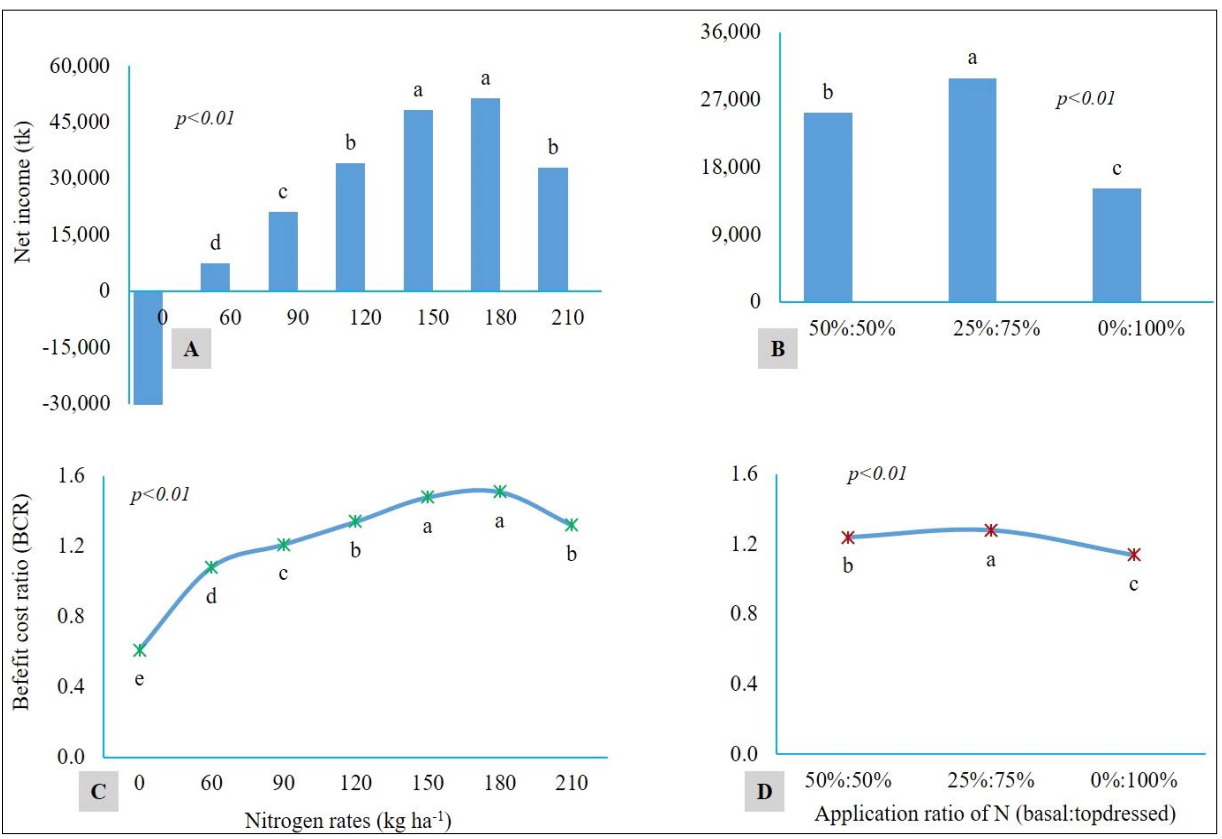

Fig 7: Net income and benefit cost ratio of sunflower at different rates $(A$ and $B)$ and application ratio $(C$ and $D)$ of nitrogen grown in the coastal soil of southwestern Bangladesh.

\section{CONCLUSION}

The results of the study revealed that individually $N$ rate and application ratio had positive influence on seed yield of sunflower. From the findings of the experiment, it can be concluded that application of $\mathrm{N} @ 150 \mathrm{~kg} \mathrm{~N} \mathrm{ha}^{-1}$ with the application ratio of $25 \%$ basal: $75 \%$ top dressed could be optimum and profitable for late sown sunflower grown under zero tillage in the coastal soils of southwestern Bangladesh. A new crop, sunflower, after transplanted aman paddy, can be benefitted the farmers with highest net return of BDT 50000.0 otherwise the land would have been remained fallow.

\section{ACKNOWLEDGEMENT}

The research work was supported by the Nutrient Management for Diversified Cropping in Bangladesh Project funded by Krishi Gobeshona Foundation (KGF), Bangladesh (ICP-II) and Australian Centre for International Agricultural Research (ACIAR), Australia (LWR-2016-136).

\section{REFERENCES}

Ali, A. and Ullah, S. (2012). Effect of nitrogen on achene protein, oil, fatty acid profile and yield of sunflower hybrids. Chilean Journal of Agricultural Research. 72(4): 564-567. DOI: 10.4067/ S0718-58392012000400016.

Awais, M., WAjid, A., Nasim, W., Ahmad, A., Saleem, M.F., Raza, M.A.S., Bashir, M.U., Rahman, M.H., Hussain J., Arshad, N. and Hoogenboom, G. (2017). Modeling the water and nitrogen productivity of sunflower using OILCROP-SUN model in Pakistan. Field Crops Research. 205: 67-77. DOI: 10.1016/j.fcr.2017.01.013.
Ayadi, S., Karmous, C., Chamekh, Z., Hammami, Z., Baraket, M., Esposito, S., Rezgui, S. and Trifa, Y. (2015). Effect of nitrogen on grain yield and nitrogen agronomic efficiency of durum wheat genotypes under different environments. Annals of Applied Biology. 168: 1-10. DOI: 10.1111/aab.12262

Brar, J.S., Mahal, S.S., Saini, K.S. and Brar, N.S. (2016). Response of sunflower yield to planting methods and irrigation schedules. Indian Journal of Agricultural Research. 50(1): 71-75. DOI: 10.18805/ijare.v50i1.8588.

Chantal, K., Basil, T., Ongor, I., Bandhushubwenge, D., Stter, N. and Felix, S. (2018). Effect of nitrogen fertilizer levels on sunflower growth and yield attributes. Pakistan Journal of Nutrition. 17(11): 557-562. DOI: 10.3923/pjn.2018.557.562.

Gomez, K.A. and Gomez, A.A. (1984). Statistical Procedure for Agricultural Research. Second Edn. International Rice Research Institute, John Wiley and Sons. New York. pp. 1-340.

Goswami, B.K. and Srivastava, G.C. (1988). Effect of foliar application of urea on leaf senescence and photosynthesis in sunflower (Helianthus annuus L.). Photo-synthetica. 22: 99-104.

Katerji, N., Van Hoorn, J.W., Hamdy, A. and Mastrorilli, M. (2003). Salinity effect on crop development and yield, analysis of salt tolerance according to several classification methods. Agricultural Water Management. 62(1): 37-66. DOI: $10.1016 / \mathrm{S} 0378-3774(03) 00005-2$.

Khanzada, A., Ansari, M.A., Chang, B.H., Rajout, A., Magsi, F.H. and Ali, U. (2016). Evaluating right timing and splitting nitrogen application rates for enhanced growth and yield of sunflower. European Academic Research. 4(7): 5986-6007.

Khatik, P., Massey, J.X. and Meena, S. (2020). Effect of nitrogen scheduling and cultivars on yield attributes and yields of sorghum (Sorghum bicolor L.). Indian Journal of Agricultural Research. 54(5): 641-645. DOI: 10.18805/IJARe.D-4572. 
Effect of Nitrogen Rate and Application Ratio on Late Sown Sunflower in Wet Soil under Zero Tillage in the Coastal Zone...

Massignam, A.M., Chapman, S.C., Hammer, G.L. and Fukai, S. (2009). Physiological determinants of maize and sunflower (Helianthus annuus L.) grain yield as affected by nitrogen supply. Field Crops Research. 113(3): 256-267. DOI: 10.1016/ j.fcr.2009.06.001.

Nasim, W., Ahmad, A., Bano, A., Olantinwo, R., Usman, M. and Khalik, T. (2012). Effect of nitrogen on yield and quality of sunflower (Helianthus annuus L.) hybrids under subhumid conditions of Pakistan. American Journal of Plant Science. 3: 243-251. DOI: 10.4236/ajps. 2012.32029.

Oyinlola, E.Y., Ogunwole, J.O. and Amapu, I.Y. (2010). Response of sunflower (helianthus annuus L.) to nitrogen application in a Savanna alfisol. HELIA. 33(52): 115-126. DOI: 10.2298/ HEL1052115O.

Paul, P.L.C., Bell, R.W., Barrett-Lennard, E.G. and Kabir, E., (2020). Straw mulch and irrigation affect solute potential and sunflower yield in a heavy textured soil in the Ganges Delta. Agricultural Water Management. 239: 106211. DOI: 10.1016/j.agwat.2020.106211
Qahar, A., Khan, Z.H., Anwar, S., Badshah, S. and Ullah H. (2010). Nitrogen use efficiency, yield and other characteristics of sunflower (Helianthus annuus L.) hybrids as affected by different levels of nitrogen. Biological Diversity and Conservation. 3(3): 121-125.

Ravishankar, G. and Malligawad, L.H. (2017). Response of sunflower to different N/P fertilizer ratios and levels of nitrogen and phosphorus. International Journal of Current Microbiology and Applied Sciences. 6(8): 980-986. DOI: 10.20546/ ijcmas.2017.608.120.

Steer, B.T., Hocking, P.J., Kortt, A.A. and Roxburgh, C.M. (1984). Nitrogen nutrition of sunflower (Helianthus annuus L.): Yield components, the timing of their establishment and seed characteristics in response to nitrogen supply. Field Crops Research. 9: 219-236. DOI: 10.1016/ 0378-4290(84) 90028-5.

Ullah, S. and Akmal, M. (2018). Response of sunflower to integrated management of nitrogen, phosphorus and Sulphur. Sarhad Journal of Agriculture. 34(4): 740-748. DOI: 10.17582/ journal.sja/2018/34.4.740.748. 